\title{
Foreign Direct Investment (FDI) by Asian and European Union (EU) Countries: The Investment Effects of Pharmaceutical Sector
}

\author{
Asif Hussain ${ }^{1}$, Xue Yang ${ }^{1}$, Lu Yali $^{1} \&$ MS Nazir ${ }^{2}$ \\ ${ }^{1}$ School of Management and Economics, North China University of water resources and Hydropower power, \\ Henan, China \\ ${ }^{2}$ Department of Management Sciences, COMSATS University, Lahore, Pakistan \\ Correspondence: Lu Yali, School of Management and Economics, North China University of water resources and \\ Hydropower power, Henan 450046, China. Tel: 86-187-3993-6530. E-mail: luyali@ ncwu.edu.cn
}

Received: June 15, 2019

Accepted: February 2, 2020

Online Published: March 10, 2020

doi:10.5539/ijef.v12n4p16

URL: https://doi.org/10.5539/ijef.v12n4p16

\begin{abstract}
The importance of Foreign Direct Investment (FDI) in current era is clearly seen in the investment made by carious companies abroad and also receiving international investment by local companies. The countries are involved in outwards and inwards FDI to receive maximum profit and long-term benefits from various FDI projects. In this regard, outwards foreign direct investment (OFDI) is also getting increased importance along with inwards FDI. The current study thereby intends to investigate the OFDI trends of companies from European Union and Asian countries whereby focusing on pharmaceutical sector particularly. Moreover, it is noteworthy that there is a rapid growth in pharmaceutical industries around the world due to advanced technology and infinite amassed need for treatment and cure options. Therefore, current study targets three European Union countries and three Asian countries, including both developed and developing nations, and investigates the OFDI patterns of pharmaceutical sector of countries. The results reveal that EU states are effective in both attracting FDI and making investments abroad and in domestic markkets; however, Netherland among three states has the highest performance in FDI inflows and outflows patterns. The analysis of Asian countries indicated that they are less effective in terms of their FDI flows compared to EU states. This is because of their developing stage and less economic growth stages. However, among three countries, Turkey presents the highest performance in attracting FDI from international markets, while Israel has highest performance in making investments abroad among three countries.
\end{abstract}

Keywords: foreign direct investment, pharmaceutical, European Union and Asian, World Trade Organization, internationalisation

\section{Introduction}

The first chapter of the study introduces the context of study and the direction of the research. The selected variables of the study are clearly discussed in introduction chapter while the research objectives, research questions, the practical implication and research gap are the main grounds of introduction chapter.

\subsection{Background}

The area of Foreign Direct Investment (FDI) has always received increased attention at national as well as international level. The concept has been studied since long, however, currently multiple improvements and development and origination of various concepts have increased the importance of FDI. Considering the importance of FDI, important motivations of the concept were developed by Dunning, Vernon or Hymer, focusing on essential theories linked to FDI. Therefore, FDI is believed to be important aspect of economic development by economists in all countries, but particularly in developing economies (Denisia, 2010). However, the extensive study on FDI issue concludes that ultimate effects of FDI are complex and they are unable to be predicted before time. FDI in Marco perspective tend to generate employment, competiveness, increased productivity and technology spillovers. The least developed countries generate increased exports, entrée to international currencies and markets and considered as important financing source for rest of the world only because of FDI (Hornberger, Battat, \& Kusek, 2011).

In 2018, the global FDI flows decreased by 13 percent in 2018 as indicated in World's Investment report 
presented by UNCTAD. The indicated a decline from US \$ 1.5 trillion (2017) to US \$ 1.3 trillion (2018). This contraction in FDI is largely triggered by the expulsion of international investments by multinational enterprises in US. Moreover, the increased transactional activity in second half of 2018 also caused tax driven fall in FDI around the world. However, since the decline was quite evident, certain countries, like US, Singapore and Hong Kong are still leading in receiving FDI, Japan, China and France are reported as largest outwards investors of FDI. In 2019-20, developed economies are expected to recover FDI because the effects of US tax reforms are expected to wind down. Eventually, the situation of developing nations is also expected to increase in terms of Foreign Direct Investment in near future (UNCTAD, 2019).

\subsection{Outward Foreign Direct Investment (OFDI)}

In this regard, national governments and countries concert their efforts to achieve a stable, transparent and predictive climate of investment in order to enhance and attract the inflows of dynamic capital. This is done through enforcement of proper contract and value for property rights that are embedded in institutions of the country as well as the macro-economic policies of the governments. It allows the efficient operation of international and domestic businesses in order to maximise the impact of development (Kang, 2012). Confirming to this, emerging markets play an important role in liberalisation of FDI regimes, deregulations, government reforms and adaptation of policies linked to market. This process poses various challenges for economies during global economic integration. Such scenarios increased the importance of outwards foreign direct investment (OFDI) from emerging economies and in 2008 indicated 16\% global OFDI flows and in 2010 this percentage increased to 28 (UNCTAD, 2011). Therefore, OFDIs are getting increased attention in literature of international business (IB) due to three main reasons; first, the growing OFDI phenomenon that still needs proper understanding; second, OFDI tend to originate from economies that are unfit to traditional theoretical frameworks proposed by developed economies; third, a proper investigation of OFDIs in home and countries is still required (Athreye \& Godley, 2009; Sauvant, 2008).

However, the phenomenon of OFDI by emerging firms of developing economies is not a new concept. Since 1970s, such emerging firms have been involved in international investment but at the particular time, the firms in the concept of emerging multinationals (EMNCs) were considered having modest foreign operations in their region with low technology products and services (Gammeltoft, Pradhan, \& Goldstein, 2010). However, this terminology achieved increased prominence by the introduction of OFDIs. Thus, in words of UNCTAD (2009), the transition and developing economies' OFDIs were 19\% in 2008 around the globe. In such percentage, Asia contributed largely, while other economies are also getting increased awareness in this regard. Considering stocks, $15 \%$ of the world stocks come from developing countries with following composition based on regions; 65.7\% of total stock from Asia; $21.7 \%$ from Latin America; 8.7\% from transition economies and $4 \%$ from Africa. In these regions, India, China and ASEAN countries; Brazil and Mexico; Russia and South Africa plays an important role. However, natural resources and services tend to produce high concentrations of OFDIs with regards to sectors involvement (Amighini \& Rabellotti, 2010).

\subsection{Pharmaceutical Sector and FDI}

Apart from these sectors, recently the issue of FDI has been increasingly getting studied in pharmaceutical sector of developing economies. The global economy has exerted increased trade of pharmaceutical sector in recent years. There is a rapid growth in pharmaceutical industries around the world due to advanced technology and infinite amassed need for treatment and cure options. Moreover, market environment for global pharmaceutical investment has also been changing and increasingly demanding the amassed incentive for FDI attraction by developing countries in order to provide medicines and technology to the population of emerging economies (Duperon \& Cinar, 2010).

The research indicates that top pharmaceutical companies in the world generate increased profits, particularly in United States, and are focusing on emerging and generic economies and markets for the preparation of revisions in potential policies. However, the area of concern creates the worry due to political transformations as well as virtual reforms in healthcare in United States and therefore the developed markets are seeking pharmaceutical imports from other developed and developing economies. This allows the countries to negotiate the discounts with international companies that might alleviate the increased profits linked to increased prices of drugs around the world (The Economist, 2008). However, this issue creates the amassed importance of pharmaceutical sector particular in case of medicines of drugs prices.

Many countries are receptive to the overview of international pharmaceutical firms that help in the capital flow and the facilitation of FDI into domestic markets. The benefits of focusing on FDI include the increased the efficiency of resource allocation, technology transfers, knowledge increment and improvements in 
infrastructures. Therefore, developing countries are increasingly demanding the improvement of capital inflows in pharmaceutical industry as well to cultivate domestic industry. Additionally, the efforts to draw FDI by pharmaceutical industry are often linked to high prices of drugs or medicines in relative markets and hence it results in the provision of adequate medicines to poorer demographics. In indicates an evident trade-off between the modest prices of drugs to conducive levels for distribution at worldwide range and countries' ability to attract FDI (Suyanto \& Salim, 2011). Therefore, pharmaceutical sector is highly dependent on FDI or OFDI. This is due to technology intensive and high capital nature of the industry. Moreover, there are high barriers for entrance in pharmaceutical sector and handful of global giants control it (Jain \& Rautela, 2018). The importance of this industry for OFDI motivated current research to study the investment effects of pharmaceutical industry of Asian and European Union countries.

\subsection{Gap and Implications}

Over the last 10 to 15 years, global pharmaceutical industry has been changed greatly. The patents' expiration on certain blockbuster drugs has urged transitional corporations in developed world, linked to research and development (R\&D), to re-examine their business models in terms of their increased sales. In this regard, certain firms are establishing alliances with generic manufacturers available in the markets of developing and developed countries. Other firms are acquiring bio-technology firms considering patent applications while others are looking for expansion in diagnostic fields and other areas. Heretofore, developing countries in the meanwhile not had to offer any protection of patents of pharmaceutical products, but they are now planning to offer such protection to chemical entities around the world under TRIPS Agreement offered by World Trade Organization (WTO). The most important contribution in this regard has been identified by India and China in literature, as these countries are increasingly interested to sell their medicaments to developed nations (UNCTAD, 2011).

The current research however aims to focus on a different perspective. The study intends to focus on outward FDI (OFDIs) of pharmaceutical sectors of three Asian countries, other than India and China, and three European Union (EU) countries and their impact on the economic growth of the countries. Hence, both developed and developing countries have been taken in the research to identify the investment effects of their pharmaceutical sector in both international and domestic market. Nevertheless, the current study is a unique one because it focuses on qualitative data that includes the figures and charts from past years related to OFDI in European and Asian countries. The study will be an important contribution to trade and development area of the selected countries. Additionally, governments, policy makers and investors will get the knowledge of OFDIs linked to pharmaceutical sector, providing basis for further research in future.

\section{Objective of Study}

The study aims to identify the investment effects of pharmaceutical sector in terms of outwards FDI while focusing on the countries from both Asia and European Union in both international and domestic markets. The study also intends to compare the OFDI performance of pharmaceutical sector of developed and developing countries. Thus, following sub-objectives are considered;

To identify the investment effect of developed countries' pharmaceutical sector in domestic market.

To identify the investment effect of developed countries' pharmaceutical sector in international market.

To identify the investment effect of developing countries' pharmaceutical sector in domestic market.

To identify the investment effect of developing countries' pharmaceutical sector in international market.

To compare the performance of developed and developing nations' pharmaceutical sector in terms of OFDI.

\subsection{Research Questions}

What is the investment influence of developed countries' pharmaceutical sector in domestic market?

What is the investment influence of developed countries' pharmaceutical sector in international market?

What is the investment influence of developing countries' pharmaceutical sector in domestic market?

What is the investment influence of developing countries' pharmaceutical sector in international market?

What is the overall performance of developed nations' pharmaceutical sector in terms of OFDI as compared to developing nations?

\section{Literature Review}

\subsection{Introduction}

The chapter of literature reviews the previous studies and the contribution of previous researchers in terms of 
selected variables of research. The detailed analysis of previous researches identifies the right direction of underlying study. Similarly, the introduction of multiple relevant theories is another importance of theoretical review chapter.

\subsection{Theoretical Underpinnings}

The research on pharmaceutical sector has been extensively studied in literature particularly in India and China, as the most prominent emerging economies to attract FDI or invest in foreign markets as OFDI. However, the importance of FDI needs to be understood properly for both developing and developed countries. Beholding beyond OLI paradigm, the discussions on internationalisation exerts the increased role of institutions. In this regard, Peng, Wang, and Jiang (2008) proposes that the vital issue for international businesses (IB) is to identify the influence of firm attributed, molded by local institutions, on the strategic decisions of MNCs from developed countries and this issue has extensively been researched (Meyer et al., 2009). However, the more important concerns recently are related to the internationalisation strategies of MNCs in emerging markets and the impact of firms from particular institutions on the outward FDI of emerging markets and this area is relatively unexamined till now (Bhaumik, Driffield, \& Pal, 2010).

The concept of outwards foreign direct investment (OFDIs) from developed multinationals to developing countries is getting increasingly important; particularly linked to institutional contribution. It has been contended that emerging MNCs use OFDIs as well as mergers and acquisitions (M\&A) to increase their competitiveness and overcoming their limited competence through fulfilling the need of location assets' portfolio. Therefore, developed countries OFDIs are important for emerging markets companies for the expansion of their activities and acquisition and development of intangible and tangible resources (Guillén \& García-Canal, 2009). However, the more recent literature indicates that OFDIs flows are also directed now from developing markets to developed countries as well, exerting the importance of OFDIs for emerging economies as well (Jain \& Rautela, 2018).

From the perspective of a bird's eye, the increased intensity and volume of OFDIs from developing economies in recent years are abstracted to third historical wave of FDI flows (Gammeltoft, 2008; Rasiah, Gammeltoft, \& Jiang, 2010). The third way is important in recovering OFDIs from Asia in repercussion of Asian financial crisis, having contagion effects in Russia, Brazil and other countries. Hence, since 1990s, many emerging economies are increasingly integrating themselves in global economy during their transition process. Additionally, emerging economies also accede to WTO and thus the processes of privatisation, liberalisation and institutional reforms have been accelerated, leading to the internationalization of MNCs (Gammeltoft, Barnard, \& Madhok, 2010).

Additionally, the study conducted by Kumar (2008) analysed OFDIs patterns, trends and determinants by enterprises in India. The results concluded a sharp increase in Indian OFDIs since 1991 and this increment was achieved as a result of sectoral and geographical shifts of Indian investments. Moreover, it was suggested that ownership advantages had been drawn by the firms from accumulated experience of production, adaptation to imported advanced technologies, production processes' cost effectiveness and product differentiation capability. Similarly, the firms already involved in exporting process were considered as outward investors. Another study by Gammeltoft (2008) considered the mounting trend of OFDIs stocks of emerging economies and focused primarily on BRICS countries. These countries are becoming politically and economically influential and thus the results indicated that BRICS countries' OFDI has been rapidly growing since last few years whereby it remains modest as compared to various developed economies. Moreover, Russia among five countries was the largest outward investor in terms of OFDI stocks, followed by China and Brazil (Gammeltoft, 2008).

India's OFDI trends had been discussed in a study over the last decade along with the identification of OFDIs driving factors. Major aim was to provide insights into investment levers to policy makers what will help to encourage OFDIs in India. The results concluded that resources needs and increased distribution expenses tend to positively affect FDI. Additionally, the paper also discussed important policy changes in India that had direct influence on OFDI and indicated that OFDI had a clear relationship with macro-level indicators, such as Fischer Open Differential and GDP (Subramanian, Sachdeva, \& Morris, 2010). The purpose of Rasiah, Gammeltoft, and Jiang (2010) study was to investigate OFDI drivers in emerging economies as well as the role of home governments for coordinating the drivers of OFDI. The background of research based on the emergence of OFDI in emerging economies and several economy firms, considered as global leaders in various industries. The study primarily focused on Asian economies whereby considering motive-based business theory and third wave of OFDI since 1990. The study highlighted technology seeking motive to be most important in third wave FDI. The evidence further conclude that home governments tend to significantly benefit successful outwards investments while addressing the motives and features of locations abroad and target industries in Asian countries. 
Singal and Jain (2012) conducted their study to identify the internationalisation path of MNCs in India considering OFDI while applying existing theories of FDI in the study. The study also examined the newer explanations of OFDI. The results indicated that existing theories fail to explain internationalisation process of Indian MNCs properly. Hence, the study developed fresh capability-based model consisted of the trends build by Indian firms regarding strategic capability before their asset accumulation at global level. Such model indicated the increasing trend in Indian firms, in terms of strategic alliances, technology acquisition and joint ventures due to OFDIs. Sudershan et al. (2012) on the other hand focused India in terms of the impact of FDI on pharmaceutical export performance of the country. The study used panel data for the research and concluded that foreign ownership negatively affects the export performance of India. It was also observed that contrary to other industries, foreign owned enterprises in pharmaceutical industry of India export less whereas they focus more on host country advantages and domestic demands (Sudershan et al., 2012).

Furthermore, the study of Zimny (2013) examined outward flow of FDI in Poland. The laissez-faire policy was adopted by Poland towards private companies, leaving the expansion and emergence of private MNCs to forces in market. Additionally, Poland was also considered as transit economy sue to increased intra-corporate flow of funds across the border within Polish and foreign MNCs, indicating as FDI flows. The empirical results reported that during 2008-2011 economic turbulence, Polish MNCs continued their investment in abroad at elevated levels. However, the profitability of such MNCs was still dependent on domestic market; therefore, increased performance was reported by Polish MNCs even during economic slowdown and financial crisis in Europe. Similarly, the OFDIs of BRICS countries in western countries during 2000-2007 were studied by Bertoni, Elia, and Rabbiosi (2013). The research disentangled various strategies of asset-seeking, market-seeking and resource-seeking abilities of countries underling vertical, horizontal and conglomerate foreign investments. The results of the study revealed that Chinese MNCs follow a relatively aggressive strategy of acquisition by acquiring the firms with low performance. Similarly, the firms involved in horizontal and conglomerate investments appeared to be largest and vertical as well as horizontal investments aimed at firms with better performance on average as compared to conglomerate investments.

The review of literature highlights the importance of outwards FDI and the pharmaceutical sector in the country. However, the contributions of pharmaceutical sector in both developing and developed nations in terms of OFDI still need further investigation. Most importantly, the theoretical underpinnings for the current study explain the importance of the FDI for underlying research direction.

\section{Hypothesis Development}

$\mathrm{H}_{1}$ : There exists an investment influence of developed countries' pharmaceutical sector in domestic market.

$\mathrm{H}_{2}$ : There exists an increase investment influence of developed countries' pharmaceutical sector in international market?

$\mathrm{H}_{3}$ : There exists an increase investment influence of developing countries' pharmaceutical sector in domestic market?

$\mathrm{H}_{4}$ : There exists an increase investment influence of developing countries' pharmaceutical sector in international market?

$\mathrm{H}_{5}$ : The overall performance of developed nations' pharmaceutical sector is superior in terms of OFDI as compared to developing nations?

\section{Methodology}

\subsection{Introduction}

The methodology chapter highlights the main direction of research, the variables or areas to target and the sources of data collection, population and sample selection and the time frame of study. The methodology section then leads the direction towards the final assessment of the collected data to generate results.

\subsection{Population and Sample}

The underlying study is a mix study because it focuses on both qualitative and quantitative data. It intends to identify the contribution of pharmaceutical sector investment in terms of foreign direct investment. However, the results in the study are analysed using only tables, charts and graphs from previous years. In this regard, the current study explores FDI trends of countries and them primarily focusing on pharmaceutical sector of multiple countries. Henceforth, the study focuses on the foreign direct investments of developed as well as developing countries round the world.

Additionally, the population of study is the countries involved in both inwards and outwards flow of FDI around 
the globe. The sample of study nevertheless includes three developed countries from European Union, including Germany, Netherlands and Spain, and three developing countries from Asia, including Turkey, Pakistan and Israel. Additionally, net FDI inflows and outflows of respective countries are discussed in the study to identify the perspective of globalisation in countries. The time frame for study is of 8 years, starting from 2010 to 2017 . The pharmaceutical sector in six countries is clearly discussed, particularly in terms of their foreign direct investment to domestic and international markets.

\subsection{Resources and Data Collection}

There are various websites available with extensive international datasets on various dimensions and patterns. Similarly, the data of FDI flows is largely available on multiple data sources and the underlying study focused primarily on the Organisation of Economic Cooperation and Development - OECD (www.oecd.org), the United Nations Conference on Trade and Development - UNCTAD (www.unctad.org), the International Trade Center ITC (www.intracent.org), and the World Bank data (www.eorldbank.org). All the data sources provides net FDI inflows and outflows in terms of \% of GDP or \$US millions or billion. Similarly, the FDI data by country or sector or bilateral FDI data is also available in the data sources of respective websites. These data sources ease the direction of study regarding the collection of relevant data.

\section{Results and Discussions}

\subsection{Introduction}

The chapter of results and discussion analyses the collected data and information related to respective topics under study. The chapter primarily discusses the pharmaceutical sector of six selected countries and then analyses the FDI flows of each country for last 8 years' time period. Additionally, the results will also analyse the investment effects of pharmaceutical sector in the world.

\subsection{Pharmaceutical Sector of Germany}

The pharmaceutical industry of Germany is the perfect combination of innovation, tradition and attractive costs. Moreover, for the purpose of pharmaceutical research, manufacturing, production or distribution at higher levels, Germany is considered the best location at international level. Hence, the country attracts various FDI inflows in their pharmaceutical sector along with the FDI outflows related to pharmaceuticals to benefit developing countries around the world.

\subsection{Pharmaceutical Sector of Netherlands}

Netherland is famous for its specialization in pharmaceutical fields and hence it is famous in European Union for its contribution of pharmaceutical industry. Hence, the country is gradually appearing as a frontier in Europe in terms of partnerships of public-private sector for the development and marketing of new drugs. Additionally, the manufacturing process as well as technologies for the respective purpose focuses on innovation and it is becoming an essential portion of Dutch portfolio. Moreover, around $\$ 1.2$ billion budget has been set aside by academia, government and private countries in Netherlands to help three imperative Dutch companies for the innovation in biochemical materials, pharmaceuticals and diagnostics, leading to increased involvement in even FDI outflows patterns of the sector.

\subsection{Pharmaceutical Sector of Spain}

The market of Spain in pharmaceutical terms is important because of its $10^{\text {th }}$ place in terms of world scientific power and $5^{\text {th }}$ place regarding scientific production in country. Hence, the country has strong health care system and various biotech companies are producing medicines in Spain for the cure of diseases more than any other country. In this regard, the pharmaceutical industry of Spain is the leader of research and development spending in EU countries. Similarly, the exports of pharmaceutical sector in country increased by $7.9 \%$ in 2015 and this ratio continue to grow steadily.

\subsection{Pharmaceutical Sector of Turkey}

The pharmaceutical sector of Turkey provides increased expansion opportunities for companies due to increased population and the movement of people to rural areas. Various high technology biotech companies are holding major pharmaceutical shares in Turkey and therefore government of the country has imposed strict controls of drugs' prices and profit margins. However, the respective sector has high inward FDI due to less number of hospitals and health care centers in Turkey and hence various foreign countries tend to heavily invest in Turkey for increased profit margins. 


\subsection{Pharmaceutical Sector of Pakistan}

Pakistan has highly forward looking and vibrant pharmaceutical industry. The industry provides high quality vital drugs to people at low prices and contributes heavily in economic development of country. However, irrespective of increased expansion of health care and pharmaceutical sectors in Pakistan, many people are unable to access modern medicines for their cure. It indicates the greater opportunity for foreign investors to invest in Pakistan but the economic conditions of Pakistan hinders the inwards flows of FDI in a large quantity. Nevertheless, the pharmaceutical sector of country is still contributing in domestic and international markets, leading the country towards increased economic growth in future.

\subsection{Pharmaceutical Sector of Israel}

Similar to Spain, the pharmaceutical sector of Israel is also famous for its Research and Development spending in the country and also the extensive international reach to various countries. Israel contains various pharmaceutical and biotechnology giants in its boundary that are contributing heavily in FDI investment, both in domestic and international market. Similarly, the country produces the medicine and exports them to other countries for the economic development and increased FDI inflows patterns, indicating a higher investment contribution of pharmaceutical sector of Israel.

\section{FDI by European Union Countries}

European countries are rich in globalisation and internationalisation mechanisms and therefore they highly prefer foreign direct investments inflows and outflows. The literature indicates that inwards and outwards FDI is commonly preferred by European Union member states because they highly contribute in the economic development and growth of Europe. The underlying study henceforth selects three important European Union states; Netherlands, Germany and Spain while examining their FDI flaws in domestic and international markets.

Figure 1 presents the net inwards FDI of three European Union States, the Netherlands, Germany and Spain (Data Source: OECD, UNCTAD and World Bank). Looking onto the line graph of EU states, it can be clearly seen that since last 8 years, the foreign markets mostly tend to invest heavily in Netherlands as compared to Germany or Spain. Nevertheless, Germany is also efficient in attracting FDI in the country, but Spain lacks this feature and needs further development in country to attract international investments. This illustrates that although all three countries are involved in globalisation perspectives, still international companies or investors focus on various other aspects to invest in a particular country because the investors are primarily concerned with earning greater profit margins or revenues against their investments.

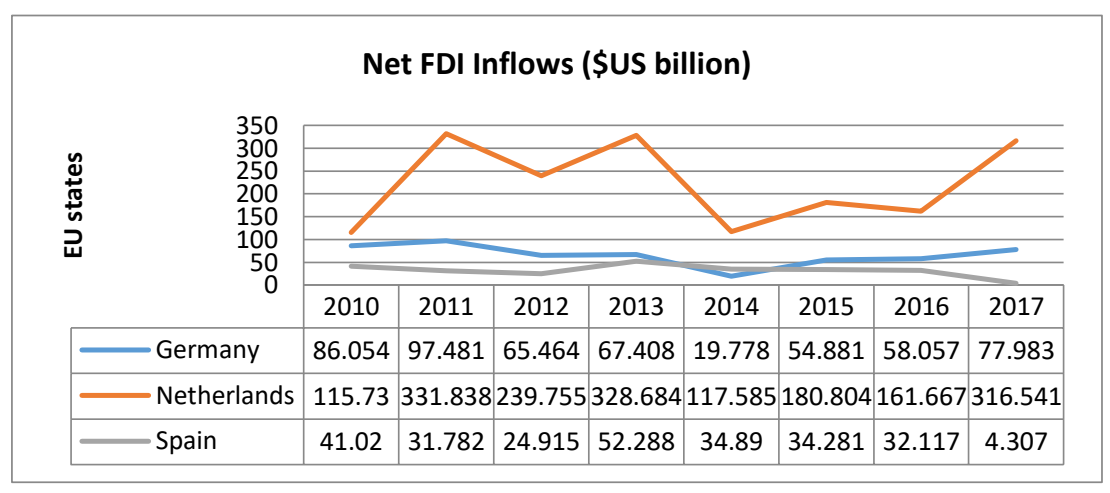

Figure 1. EU states Net inward FDI

Figure 1, 2, 7, 8, 12, 13 are not obtained from net, instead the data was obtained from mentioned data sources and then data was compiled in excel sheet to get the line graph as shown in figure 1.

Similarly, Figure 2 is the illustration of net outwards FDI of three European Union States. The countries are not only attracting FDI in their domestic markets, instead they are also efficient in investing other international markets in terms of various sectors distribution. However, the net outward FDI of three EU states again indicates that Netherlands is the most effective and efficient country to invest in foreign markets as followed by Germany and then Spain. This is similar to the inwards FDI indication In Figure 1 that Netherlands is most effective in attracting FDI from international markets. It shows that not all European Union states are efficient in their FDI flows; instead more developments and improvements in sectors are needed to create a exclusive place in FDI flows around the world. 


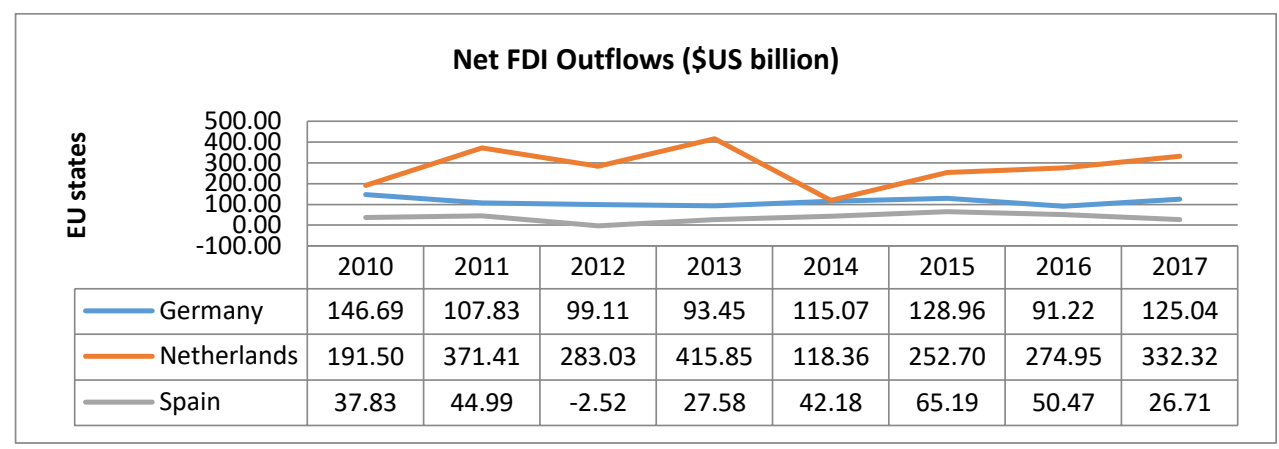

Figure 2. EU states Net outward FDI

The results of Figure 1 and 2 can also be confirmed with Figure 3 that illustrates the net FDI international investments of various EU states in 2017 and their contribution to the economic growth and development of Europe. The pie chart indicates that Europe contributes heavily in net FDI international investments (53.7\%), followed by the other countries around the world (24.6\%). However, USA only contributes $18.9 \%$ to FDI international investments and BRICS economies have the smallest contribution (2.8\%) in overall FDI investments abroad. Nevertheless, the highest contribution of Europe in FDI illustrates that Luxemburg was the most efficient country to contribute in FDI investments abroad (24\%) followed by Netherlands (22\%). The Germany and Spain on the other hand had 3\% and 6\% overall contribution in 2017 net international investments FDI. Henceforth, among the chosen countries in underlying study, the FDI efficiency of Netherlands is quite evident from the results.
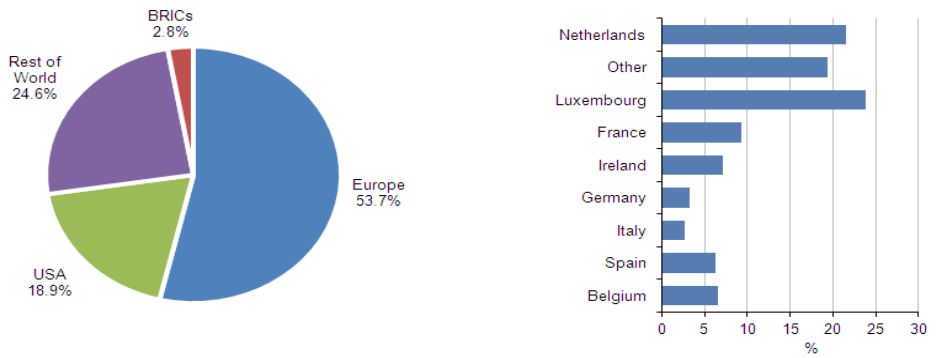

Figure 3. Net FDI international investments abroad 2017

Looking beyond the FDI inflows and outflows of European Union States, Figure 4, 5 and 6 presents the bilateral FDI flows and by sector FDI flows of three economies. Figure 3 presents the percentage of bilateral FDI, from Netherlands to other countries. According to pie chart, FDI inflows in Netherlands' domestic market are 6.1\%, however, the outflows FDI of Netherland are mostly directed towards Luxemburg (23.8\%), and the rest of the world (14.7\%). Nevertheless, Netherlands also tend to invest in other states of Europe, such as Cyprus (6.6\%), Belgium (5.5\%), Lithuania and Switzerland (5\% each), Czech Republic (4.9\%) and USA (4.3\%) etc. In this regard, country has established strong relationships with other countries in terms of foreign investments.

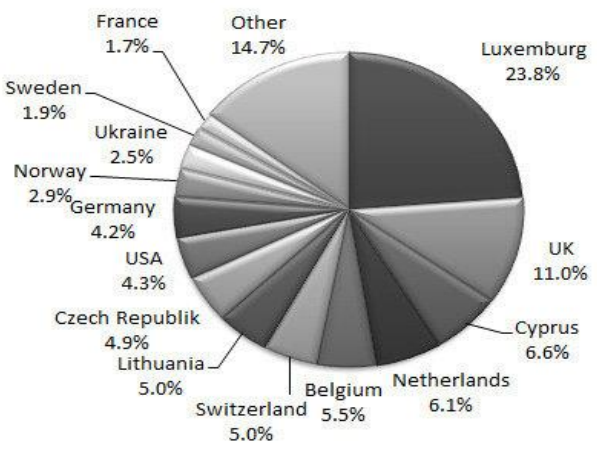

Figure 4. Netherlands bilateral FDI 
On the other hand, Figure 5 indicates the FDI flows of Spain by sector while highlighting that real estate, infrastructure and buildings industry $(29.17 \%)$ tend to contribute heavily in FDI flows of the country, while financial service (17.18\%) stands and second and retail and whole sale industry (12.19\%) stands at third position. Overall, the real estate and infrastructure attracts the attention of most investors in the country and invests heavily to generate greater expected returns in future.

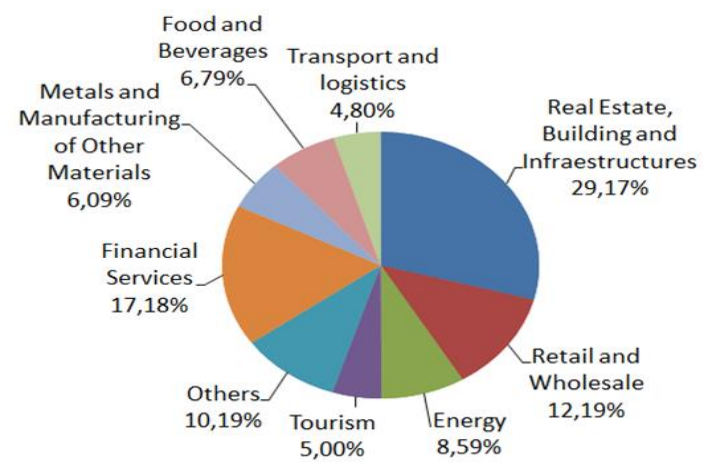

Figure 5. FDI flows of Spain by sector

In the same manner, Figure 6 presents the FDI flows of Germany considering the sector contribution of country. The pie chart indicates that ICT and software sector (18\%) of Germany heavily contributes in FDI flows of the country, followed by financial and business industry and automobile and machinery industry (15\% each). However, pharmaceutical sector contributes only 5\% in FDI flows of country. This indicates that overall technology industry is more evident in Germany for attracting international investments and also making FDI investments abroad.

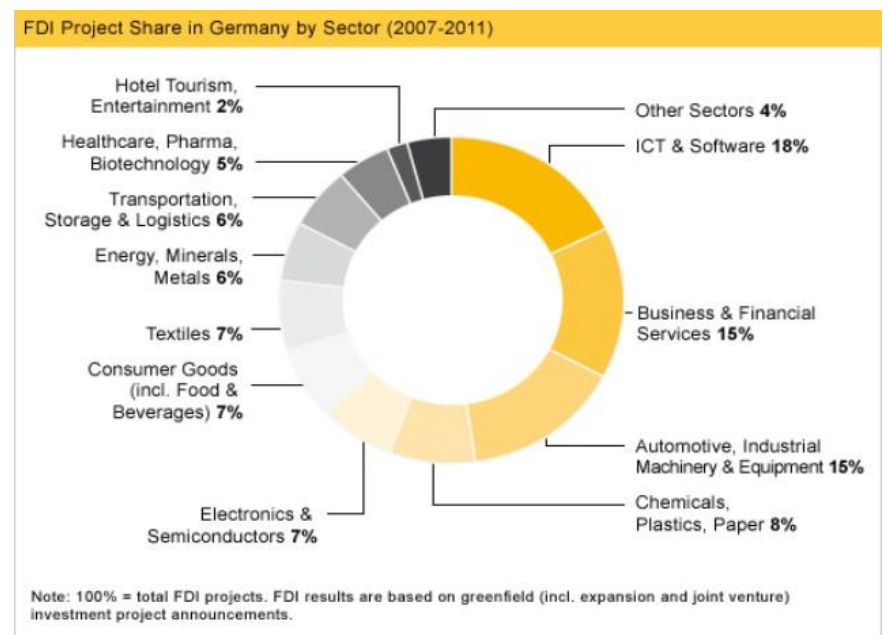

Figure 6. FDI flows of Germany by sector

\section{FDI by Asian Countries}

Apart from EU states, the FDI flows of Asian countries are also important to be analysed for assessing their overall contribution in FDI flows around the world. Therefore, underlying study targets three countries in Asia; Turkey, Pakistan and Israel for assessing their FDI inflows and outflows and analyzing their investments in domestic and international markets. In this regard, Figure 7 indicates that net FDI outflows of selected Asian countries and illustrates that Israel is more effective in investing in international markets while the poor performance is presented by Pakistan who lacks in making investments in international markets. The condition of Turkey is moderate as it tends to attract more inwards FDI than to invest in international markets. 


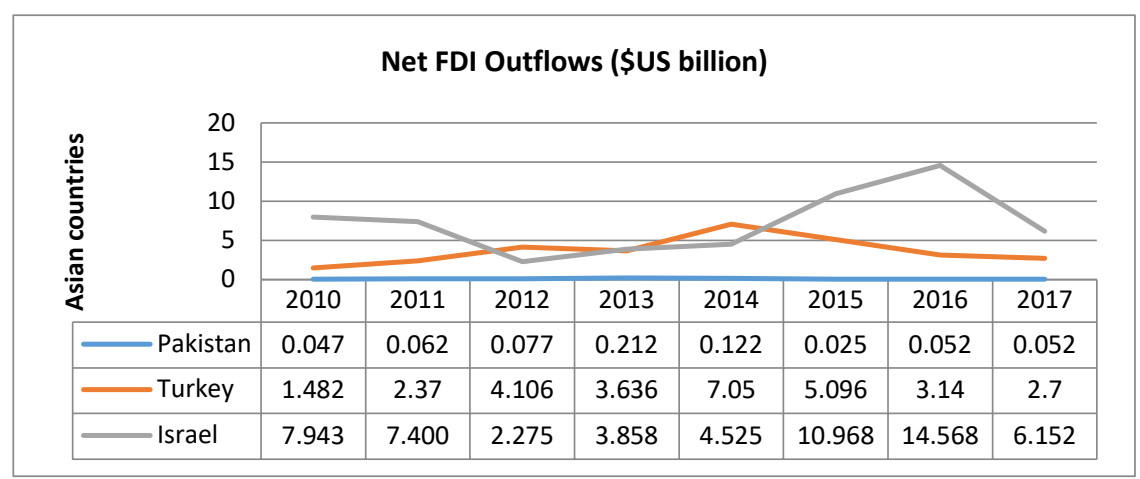

Figure 7. Asian countries' net outward FDI

On contrary, Figure 8 presents the net inward FDI flows while indicating that Pakistan also lacks in attracting international investment along with making reduced investments abroad. The net inflows and outflows FDI of Pakistan are so weak to make the country an effective one for investments. On the other hand, Turkey attracts various international investors to avail the increased investment opportunities in Turkey with the aim of generating increased returns. The condition of Israel is however moderate in attracting international investments.

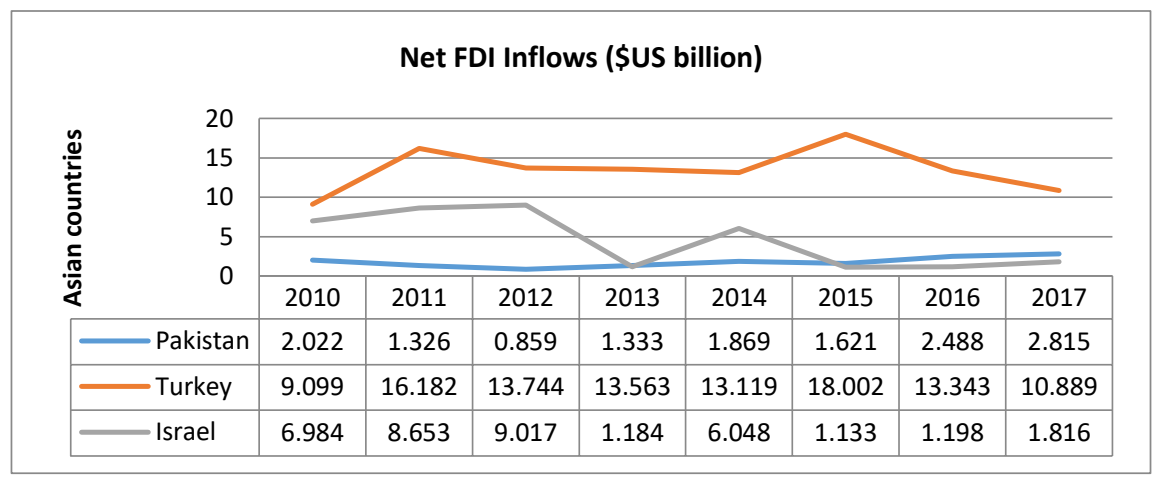

Figure 8. Asian countries' net inward FDI

The analysis of Asian Countries FDI inflows and outflows also indicates that Turkey is efficient in attracting FDI and also making outward FDI to other countries. Figure 9 and 10 presents the bileteral FDI inflows and outflows of Turkey repectively and indicates that UK (11.09\%) tends to invest heavily in Turkey followed by Netherlands (11.60\%) while the remainign world contributes to $23.55 \%$ in terms of investment in Turkey. Similarly, Turkey tends to invest heavily in Netherlands (28\%) followed by Azerbaijan (16\%) apart from various other countries.

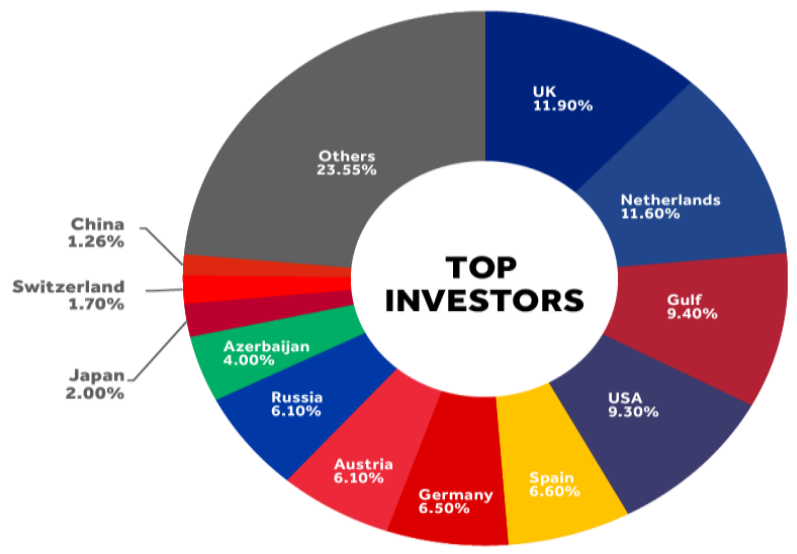

Figure 9. Bilateral FDI inflows in Turkey 


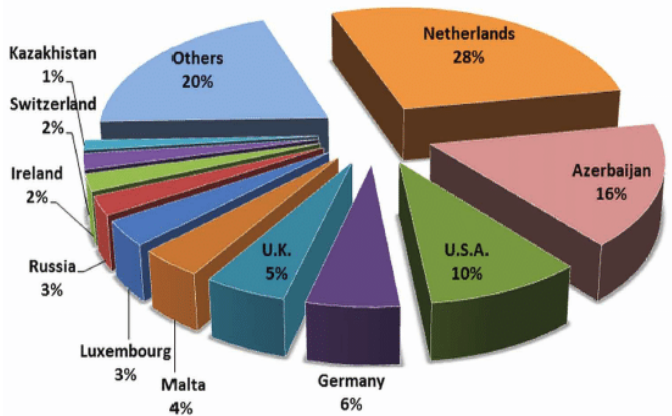

Figure 10. Bilateral FDI outflows from Turkey

In the same manner, Figure 11 presents FDI outflows of Israel in Germany by sector and indicates that sales and marketing industry, construction industry and textile industry of Israel mostly invests in Germany while pharmaceutical sector only make $6.3 \%$ foreign investments. Henceforth, the FDI outflows are largely contributed by marketing sector.

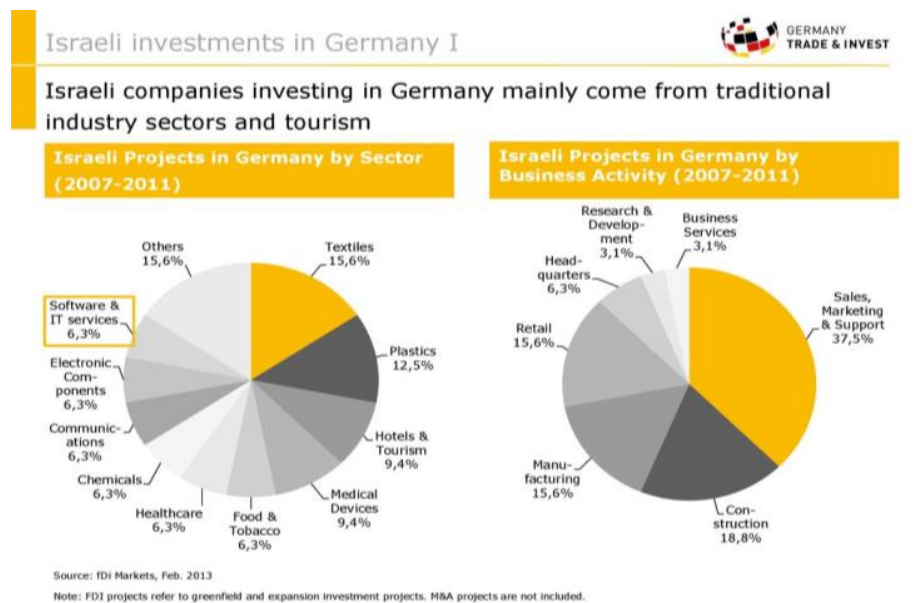

Figure 11. Bilateral FDI outflows from Israel by sector

\section{FDI Outflows by Pharmaceutical Sector}

Looking in all these FDI patterns, the discussion on FDI of pharmaceutical sector has been largely carried out by India and China, however, other countries have not concentrated on their pharmaceutical sectors' FDI investment at all. Therefore, the analysis of pharmaceutical sector in current study analyses the FDI outflows by respective sector of selected countries in rest of the world.

In this regard, Figure 12 presents the FDI outflows by pharmaceutical sector of Pakistan, Turkey and Israel. The statistics of FDI in last 8 years indicate that pharmaceutical sector of Israel is the only effective in terms of making foreign investments abroad. However, the respective sector of Turkey is also making their efforts to invest abroad. Both the countries nevertheless have showed upturns and downturns in last 8 years regarding investments by pharmaceutical sector as indicated by FDI statistics in figure. The years 2013 and 2014 were productive ones, while currently less investment patterns have been reported by pharmaceutical sector of both countries.

On the other hand, the condition of Pakistan's pharmaceutical sector is quite poor due to the reduced and poor condition of its overall net FDI inflows and outflows. Hence, the economy of Pakistan needs major developments and improvements to stand in international markets' arena. Additionally, only Israel is making increased contribution in domestic and international market through pharmaceutical sector. Turkey stands on the send position to make domestic investment through pharmaceutical sector only, while the sector does not contribute in international investments. The condition of Pakistani is quite poor in terms of domestic and international investment through pharmaceutical sector. This might be because of poor economic conditions of the country in attracting and making investments domestically and internationally. Therefore, Pakistan needs to strong its pharmaceutical sector to make attractive OFDI. 


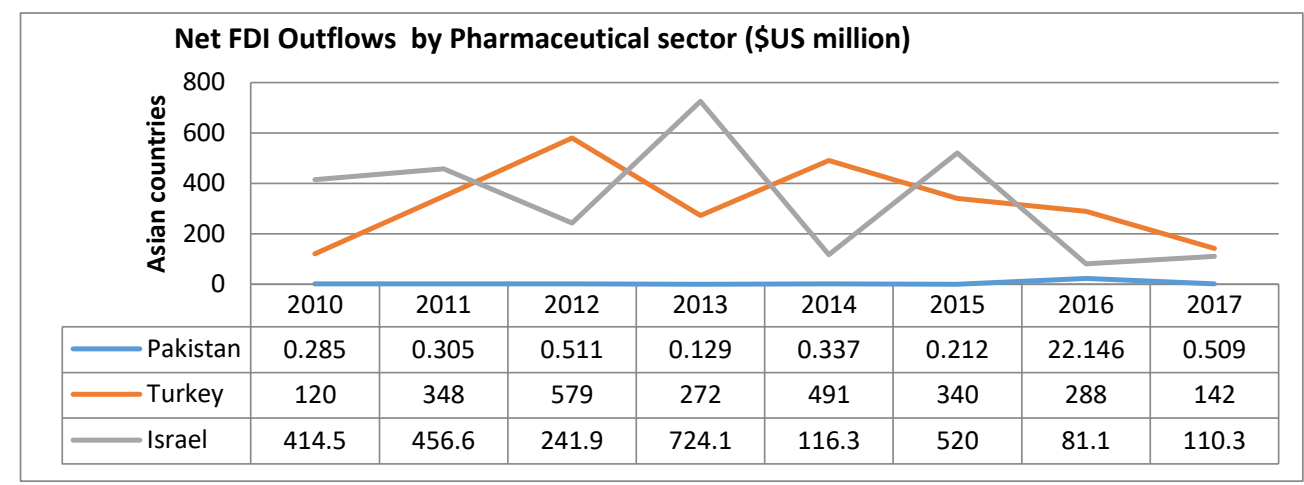

Figure 12. Pharmaceutical sector's FDI outflies by Asian Countries

Another dimension sheds the light on pharmaceutical sector of EU member states and Figure 13 presents the FDI statistics in the respective manner. According to the line graph, the pharmaceutical industry of Netherlands among three countries is making increased investments abroad since last 8 years and 2013 was the golden year. This statistic is not followed by the pharmaceutical sector of Germany and both Spain. However, the year 2015 for Netherlands was a sudden downturn in the respective sector, but the pharmaceutical sector again sustained its position in 2016 and 2017 as evident from the figure.

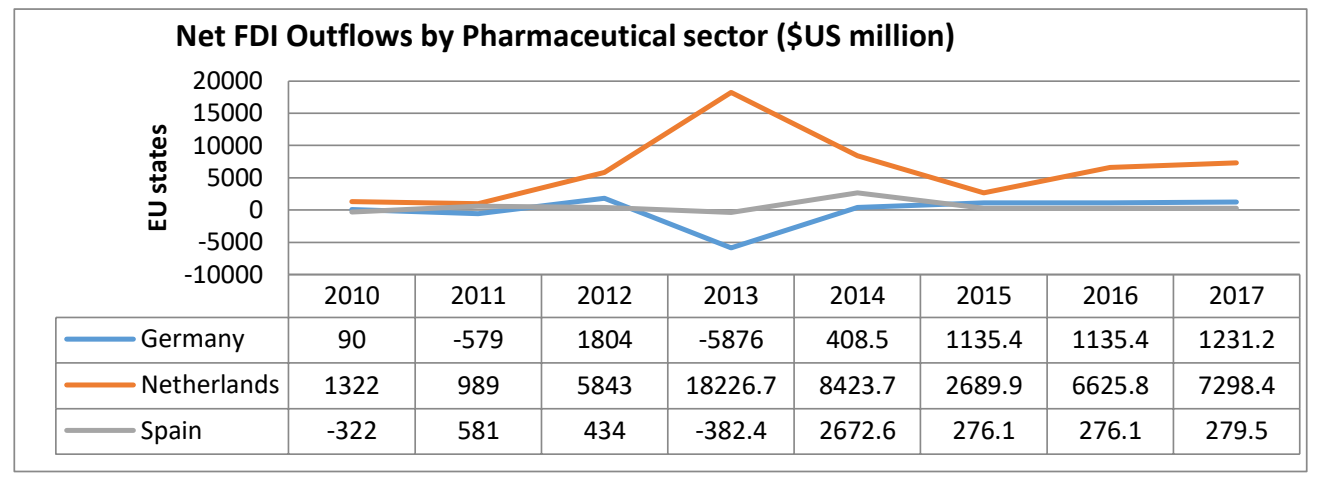

Figure 13. Pharmaceutical sector's FDI outflows by EU states

The respective sector of Germany and Spain on the other hand presents different and disappointing views. The pharmaceutical industry in both countries is ineffective in making international investments abroad, particularly in case of Germany. However, the sector undoubtedly makes increased investment in domestic market and hence, the pharmaceutical industry of both Spain and Germany is efficient in making Research and Development spending in the country.

Looking into the information of tables, graphs and pictures, it is clearly evident that that pharmaceutical sector of European Union countries is somehow efficient in contributing to Foreign Direct Investment. Nevertheless, the pharmaceutical sector of European Countries has increased influence on investment in domestic market, because all three countries (Germany, Netherlands and Spain) somehow tend to invest in domestic market through pharmaceutical sector. On contrary, the pharmaceutical sector of European Countries has low influence on investment in international market because only Netherlands tend to invest increasingly in international market through pharmaceutical sector. Eventually, hypothesis $\mathrm{H}_{1}$ is accepted with high investment influence of pharmaceutical sector and hypothesis $\mathrm{H}_{2}$ is rejected with low investment influence of pharmaceutical sector.

On the other hand, the pharmaceutical sector of Asian countries is also somehow efficient in contributing to Foreign Direct Investment. Nevertheless, the pharmaceutical sector of European Countries has moderate influence on investment in domestic market, because only Israel and Spain somehow tend to invest in domestic market through pharmaceutical sector but Pakistan does not contribute efficiently in this regard. Similarly, the pharmaceutical sector of European Countries has low influence on investment in international market because only Israel tends to invest increasingly in international market through pharmaceutical sector. Eventually, hypothesis $\mathrm{H}_{3}$ is accepted with moderate investment influence of pharmaceutical sector and hypothesis $\mathrm{H}_{4}$ is 
rejected with low investment influence of pharmaceutical sector. This also indicates that performance of developed nations' pharmaceutical sector is somehow superior in terms of OFDI as compared to developing nations, thus accepting hypothesis $\mathrm{H}_{5}$.

\section{Conclusion}

The increased globalisaiton and internationalization has heightened the interest of countries and international markets towards foreign direct investments. FDI is believed to be important aspect of economic development by economists in all countries, but particularly in developing economies. The least developed countries generate increased exports, entrée to international currencies and markets and considered as important financing source for rest of the world only because of FDI. However, the phenomenon of outwards Foreign Direct Investment OFDI by emerging firms of developing economies is not an effective concept and it indicates the movement of FDI from host country to other countries as termed by FDI outflows. The re current study henceforth analyses the FDI of European Union states as well as Asian countries to assess their flows of investments in international and national level. Additionally, the study focused on a particular sector, pharmaceutical industry of countries to assess their contribution in OFDI.

The global economy has exerted increased trade of pharmaceutical sector in recent years. There is a rapid growth in pharmaceutical industries around the world due to advanced technology and infinite amassed need for treatment and cure options. The efforts to draw FDI by pharmaceutical industry are often linked to high prices of drugs or medicines in relative markets and hence it results in the provision of adequate medicines to poorer demographics. In indicates an evident trade-off between the modest prices of drugs to conducive levels for distribution at worldwide range and countries' ability to attract FDI and invest abroad.

The study therefore included three European Union States; Netherlands, Germany and Spain and three Asian countries; Turkey, Pakistan and Israel in the analysis to identify the position of six countries in terms of their FDI inflows and outflows and also to highlight the performance of pharmaceutical sector in OFDI. The results were obtained through FDI statistics of the countries and the graphs and pie charts of the data thus presented influential outcomes.

The results in this regard indicated that EU states are effective in both attracting FDI and making investments abroad; however, Netherland among three states has the highest performance in FDI inflows and outflows patterns. Germany on the other hand is also proficient in attracting FDI and making investments abroad but at a moderate level. On part of Spain, the country stays behind the other two countries in its performance.

The analysis of Asian countries indicated that they are less effective in terms of their FDI flows compared to EU states. This is because of their developing stage and less economic growth stages. However, among three countries, Turkey presents the highest performance in attracting FDI from international markets, while Israel has highest performance in making investments abroad among three countries. Pakistan, however, lacks far behind these countries and indicates a poor performance in its FDI flows.

Analyzing the pharmaceutical sectors of both EU states and Asian countries illustrated that Netherlands pharmaceutical and chemical industry is very effective in making investments in domestic and international markets, while the respective sector in Germany and Spain is far behind their approach to international investment. On the other hand, the pharmaceutical sector of Turkey and Israel in Asian countries although makes investments in domestic and international markets, but they are not steady in their investments. Instead, both countries face upturns and downturns with passing years. The condition of Pakistan's pharmaceutical sector is low as it is unable to make any large investments in international markets even though it invests in domestic market.

The study was limited to pharmaceutical sector only; instead other sectors make greater contribution in OFDI. Additionally, there are various unions available with important states that can be included in future studies with the analysis of more sectors. The future research must also focus on the detailed analysis of bilateral FDI flows of various countries.

\section{References}

Adams, S. (2010). Intellectual property rights, investment climate and FDI in developing countries. International Business Research, 3(3), 201. https://doi.org/10.5539/ibr.v3n3p201

Amighini, A., \& Rabellotti, R. (2010). Outward FDI from developing country MNEs as a channel for technological catch-up. https://doi.org/10.2139/ssrn.1603569

Assunção, S., Forte, R., \& Teixeira, A. (2011). Location determinants of FDI: A literature review. 
Athreye, S., \& Godley, A. (2009). Internationalization and technological leapfrogging in the pharmaceutical industry. Industrial and Corporate Change, 18, 295-323. https://doi.org/10.1093/icc/dtp002

Bénassy-Quéré, A., Coupet, M., \& Mayer, T. (2007). Institutional determinants of foreign direct investment. World Economy, 30(5), 764-782. https://doi.org/10.1111/j.1467-9701.2007.01022.x

Bertoni, F., Elia, S., \& Rabbiosi, L. (2013). Outward FDI from the BRICs: Trends and patterns of acquisitions in advanced countries. In Emerging Economies and Firms in the Global Crisis (pp. 47-82). Palgrave Macmillan, London. https://doi.org/10.1057/9781137277473_3

Bhaumik, S. K., \& Driffield, N. (2011). Direction of outward FDI of EMNEs: Evidence from the Indian pharmaceutical sector. Thunderbird International Business Review, 53(5), 615-628. https://doi.org/10.1002/tie.20438

Bhaumik, S. K., Driffield, N., \& Pal, S. (2010). Does ownership structure of emerging-market firms affect their outward FDI? The case of the Indian automotive and pharmaceutical sectors. Journal of International Business Studies, 41(3), 437-450. https://doi.org/10.1057/jibs.2009.52

Buckley, P. J. (2011). The theory of international business pre-Hymer. Journal of World Business, 46(1), 61-73. https://doi.org/10.1016/j.jwb.2010.05.018

Büthe, T., \& Milner, H. V. (2008). The politics of foreign direct investment into developing countries: increasing FDI through international trade agreements?. American Journal of Political Science, 52(4), 741-762. https://doi.org/10.1111/j.1540-5907.2008.00340.x

Denisia, V. (2010). Foreign direct investment theories: An overview of the main FDI theories.

Duperon, W. O., \& Cinar, E. (2010). Global Competition versus Regional Interests: FDI and Pharmaceuticals in India. J. Int'l Com. L. \& Tech., 5, 181.

Faeth, I. (2009). Determinants of foreign direct investment-a tale of nine theoretical models. Journal of Economic Surveys, 23(1), 165-196. https://doi.org/10.1111/j.1467-6419.2008.00560.x

Gammeltoft, P. (2008). Emerging multinationals: outward FDI from the BRICS countries. Georgia Institute of Technology. https://doi.org/10.1504/IJTG.2008.016184

Gammeltoft, P., Barnard, H., \& Madhok, A. (2010). Emerging multinationals, emerging theory: Macro-and micro-level perspectives. https://doi.org/10.1016/j.intman.2010.03.001

Gammeltoft, P., Pradhan, J. P., \& Goldstein, A. (2010). Emerging multinationals: Home and host country determinants and outcomes. International Journal of Emerging Markets, 5(3/4), 254-265. https://doi.org/10.1108/17468801011058370

Gereffi, G. (2017). The pharmaceutical industry and dependency in the Third World (Vol. 4964). Princeton University Press.

Guillén, M. F., \& García-Canal, E. (2009). The American model of the multinational firm and the "new" multinationals from emerging economies. Academy of Management Perspectives, 23(2), 23-35. https://doi.org/10.5465/amp.2009.39985538

Hattari, R., \& Rajan, R. S. (2009). Understanding bilateral FDI flows in developing Asia. Asian-Pacific Economic Literature, 23(2), 73-93. https://doi.org/10.1111/j.1467-8411.2009.01232.x

Hornberger, K., Battat, J., \& Kusek, P. (2011). Attractive FDI: how much does investment climate matter?

Jain, H., \& Rautela, M. (2018). FDI in Indian Pharmaceutical Sector. https://doi.org/10.2139/ssrn.3153434

Jakobsen, J., \& Jakobsen, T. G. (2011). Economic nationalism and FDI: The impact of public opinion on foreign direct investment in emerging markets, 1990-2005. Society and Business Review, 6(1), 61-76. https://doi.org/10.1108/17465681111105841

Kang, A. (2012). Evaluating Effects of FDI in Developing Economies-The Curious Case of Indian Pharmaceutical Industry. Amity Management Review, 2(2).

Kinda, T. (2010). Investment climate and FDI in developing countries: firm-level evidence. World Development, 38(4), 498-513. https://doi.org/10.1016/j.worlddev.2009.12.001

Koenig, P., \& MacGarvie, M. (2011). Regulatory policy and the location of bio-pharmaceutical foreign direct investment in Europe. Journal of Health Economics, 30(5), 950-965. https://doi.org/10.1016/j.jhealeco.2011.07.005 
Kok, R., \& Acikgoz, E. B. (2009). Analyses of FDI determinants in developing countries. International Journal of Social Economics, 36(1/2), 105-123. https://doi.org/10.1108/03068290910921226

Kumar, N. (2008). Emerging MNCs: trends, patterns, and determinants of outward FDI by Indian enterprises. In New Dimensions of Economic Globalization: Surge of Outward Foreign Direct Investment from Asia (pp. 141-167). https://doi.org/10.1142/9789812793119_0006

Majeed, M. T., \& Ahmad, E. (2009). An Analysis of Host Country Characteristics that Determine FDI in Developing Countries: Recent Panel Data Evidence. Lahore Journal of Economics, 14(2). https://doi.org/10.35536/lje.2009.v14.i2.a3

Meyer, K. E., Estrin, S., Bhaumik, S. K., \& Peng, M. W. (2009). Institutions, resources, and entry strategies in emerging economies. Strategic Management Journal, 30(1), 61-80. https://doi.org/10.1002/smj.720

Nicolini, M., \& Resmini, L. (2010). FDI spillovers in new EU member states. Economics of Transition, 18(3), 487-511. https://doi.org/10.1111/j.1468-0351.2009.00379.x

Peng, M. W., Wang, D. Y., \& Jiang, Y. (2008). An institution-based view of international business strategy: A focus on emerging economies. Journal of International Business Studies, 39(5), 920-936. https://doi.org/10.1057/palgrave.jibs.8400377

Popovici, O. C., \& Călin, A. C. (2014). FDI theories. A location-based approach. Romanian Economic Journal, 17(53).

Rasiah, R., Gammeltoft, P., \& Jiang, Y. (2010). Home government policies for outward FDI from emerging economies: Lessons from Asia. International Journal of Emerging Markets, 5(3/4), 333-357. https://doi.org/10.1108/17468801011058415

Sauvant, K. P. (2009). The rise of transnational corporations from emerging markets: Threat or opportunity? Edward Elgar Publishing. https://doi.org/10.4337/9781848441460

Singal, A., \& Jain, A. K. (2012). Outward FDI trends from India: Emerging MNCs and strategic issues. International Journal of Emerging Markets, 7(4), 443-456. https://doi.org/10.1108/17468801211264342

Subramanian, R., Sachdeva, C., \& Morris, S. (2010). FDI Outflows from India: An Examination of the Underlying Economics, Policies, and their Impacts.

Sudershan, K., Muppani, V. R., Khan, M., \& Ali, A. (2012). Foreign Direct Investment and Export Performance of Pharmaceutical Firms in India: An Empirical Approach.

Suyanto, \& Salim, R. (2011). Foreign direct investment spillovers and technical efficiency in the Indonesian pharmaceutical sector: firm level evidence. Applied Economics, 45(3), 383-395. https://doi.org/10.1080/00036846.2011.605554

The Economist. (2008). Pharmaceuticals racing Down the Pyramid: Big Drugmakers' Love Affair with America is coming to an End. Retrieved November 152018 from https://www.economist.com/business/2008/11/13/racing-down-the-pyramid

UNCTAD. (2009). Trade and Development. New York and Geneva: United Nations Conference on Global crisis Climate change mitigation and development.

UNCTAD. (2011a). Global Investment Trends Monitor. New York and Geneva: United Nations Conference on Trade and Development.

UNCTAD. (2011b). Investment in Pharmaceutical Production in the Least Developed Countries; a Guide for Policymakers and Investment Promotion Agencies. United Nations Conference on Trade and Development.

UNCTAD. (2019). Global foreign direct investment sides for third consecutive year. United Nations Conference on Trade and Development.

Vasyechko, O. (2012). A review of FDI theories: An application for transition economies. International Research Journal of Finance and Economics, 2(89), 118-137.

Yang, Y., Yang, X., Chen, R. R., \& Allen, J. P. (2014). What drives emerging-economy outbound FDI decisions to obtain strategic assets? Asian Business \& Management, 13(5), 379-410. https://doi.org/10.1057/abm.2014.15

Zimny, Z. (2013). Outward FDI from Poland and its policy context, 2012. https://doi.org/10.2139/ssrn.2433916 


\section{Appendix}

\section{Hypotheses acceptance or rejection}

The performance of European Union and Asian countries in terms of FDI categories as well as the acceptable and rejection of hypotheses is shown in Table 1 and 2 below.

Table A1. FDI performance of European Union and Asian countries

\begin{tabular}{llll}
\hline & \multicolumn{2}{l}{ European Union Countries } \\
\hline FDI categories; & Germany & Netherlands & Spain \\
\hline Increased net FDI inflows & Moderate & High & Low \\
Increased net FDI outflows & Low & High & Moderate \\
FDI outflows by pharmaceutical sector & Moderate & High & Low \\
Increase influence of pharmaceutical sector's investment in domestic market & Below high & High & Below high \\
Increase influence of pharmaceutical sector's investment in international market & Low & High & Low \\
\hline & Asian Countries & & Israel \\
\hline FDI categories; & Turkey & Pakistan & Moderate \\
\hline Increased net FDI inflows & High & Low & High \\
Increased net FDI outflows & Moderate & Low & High \\
FDI outflows by pharmaceutical sector & Moderate & Low & High \\
Increase influence of pharmaceutical sector's investment in domestic market & Moderate & Low & High \\
Increase influence of pharmaceutical sector's investment in international market & Low & Low & \\
\hline
\end{tabular}

Table A2. Hypotheses Acceptance or Rejection

\begin{tabular}{ll}
\hline Hypotheses & Accept / Reject \\
\hline $\mathrm{H}_{1}$ : There is an increase investment influence of developed countries' pharmaceutical sector in & Accept, with high influence \\
domestic market. & \\
$\mathrm{H}_{2}$ : There is an increase investment influence of developed countries' pharmaceutical sector in & Reject, with low influence \\
international market? & \\
$\mathrm{H}_{3}$ : There is an increase investment influence of developing countries' pharmaceutical sector in & Accept, with moderate influence \\
domestic market? & \\
$\mathrm{H}_{4}$ : There is an increase investment influence of developing countries' pharmaceutical sector in & Reject, with low influence \\
international market? & \\
$\mathrm{H}_{5}$ : The overall performance of developed nations' pharmaceutical sector is superior in terms of & Accept, with moderate influence \\
OFDI as compared to developing nations? & \\
\hline
\end{tabular}

Appendix A1. Data Source: OECD, UNCTAD and World Bank

\begin{tabular}{|c|c|c|c|}
\hline \multicolumn{4}{|c|}{ Net FDI Outflows (\$US billion) } \\
\hline Asian Countries & Pakistan & Turkey & Israel \\
\hline 2010 & 0.047 & 1.482 & 7.943 \\
\hline 2011 & 0.062 & 2.37 & 7.4 \\
\hline 2012 & 0.077 & 4.106 & 2.275 \\
\hline 2013 & 0.212 & 3.636 & 3.858 \\
\hline 2014 & 0.122 & 7.05 & 4.525 \\
\hline 2015 & 0.025 & 5.096 & 10.968 \\
\hline 2016 & 0.052 & 3.14 & 14.568 \\
\hline 2017 & 0.052 & 2.7 & 6.152 \\
\hline \multicolumn{4}{|c|}{ Net FDI Outflows (\$US billion) } \\
\hline EU Countries & Germany & Netherlands & Spain \\
\hline 2010 & 146.69 & 191.5 & 37.83 \\
\hline 2011 & 107.83 & 371.41 & 44.99 \\
\hline 2012 & 99.11 & 283.03 & -2.52 \\
\hline 2013 & 93.45 & 415.85 & 27.58 \\
\hline 2014 & 115.07 & 118.36 & 42.18 \\
\hline 2015 & 128.96 & 252.7 & 65.19 \\
\hline 2016 & 91.22 & 274.95 & 50.47 \\
\hline 2017 & 125.04 & 332.32 & 26.71 \\
\hline
\end{tabular}




\begin{tabular}{|c|c|c|c|}
\hline \multicolumn{4}{|c|}{ Net FDI Inflows (\$US billion) } \\
\hline Asian Countries & Pakistan & Turkey & Israel \\
\hline 2010 & 2.022 & 9.099 & 6.984 \\
\hline 2011 & 1.326 & 16.182 & 8.653 \\
\hline 2012 & 0.859 & 13.744 & 9.017 \\
\hline 2013 & 1.333 & 13.563 & 1.184 \\
\hline 2014 & 1.869 & 13.119 & 6.048 \\
\hline 2015 & 1.621 & 18.002 & 1.133 \\
\hline 2016 & 2.488 & 13.343 & 1.198 \\
\hline 2017 & 2.815 & 10.889 & 1.816 \\
\hline \multicolumn{4}{|c|}{ Net FDI Inflows (\$US billion) } \\
\hline EU Countries & Germany & Netherlands & Spain \\
\hline 2010 & 86.054 & 115.73 & 41.02 \\
\hline 2011 & 97.481 & 331.838 & 31.782 \\
\hline 2012 & 65.464 & 239.755 & 24.915 \\
\hline 2013 & 67.408 & 328.684 & 52.288 \\
\hline 2014 & 19.778 & 117.585 & 34.89 \\
\hline 2015 & 54.881 & 180.804 & 34.281 \\
\hline 2016 & 58.057 & 161.667 & 32.117 \\
\hline 2017 & 77.983 & 316.541 & 4.307 \\
\hline
\end{tabular}

Appendix A2. Data Source: OECD, UNCTAD and World Bank

\begin{tabular}{llll}
\hline \multicolumn{4}{l}{ Net FDI Outflows by Pharmaceutical sector (\$US million) } \\
\hline Asian Countries & Pakistan & Turkey & Israel \\
\hline $\mathbf{2 0 1 0}$ & 0.285 & 120 & 414.5 \\
$\mathbf{2 0 1 1}$ & 0.305 & 348 & 456.6 \\
$\mathbf{2 0 1 2}$ & 0.511 & 579 & 241.9 \\
$\mathbf{2 0 1 3}$ & 0.129 & 272 & 724.1 \\
$\mathbf{2 0 1 4}$ & 0.337 & 491 & 116.3 \\
$\mathbf{2 0 1 5}$ & 0.212 & 340 & 520 \\
$\mathbf{2 0 1 6}$ & 22.146 & 288 & 81.1 \\
$\mathbf{2 0 1 7}$ & 0.509 & 142 & 110.3 \\
\hline & Net FDI Outflows by Pharmaceutical sector (\$US million) & \\
\hline EU Countries & Germany & Netherlands & Spain \\
\hline $\mathbf{2 0 1 0}$ & 90 & 1322 & -322 \\
$\mathbf{2 0 1 1}$ & -579 & 989 & 581 \\
$\mathbf{2 0 1 2}$ & 1804 & 5843 & 434 \\
$\mathbf{2 0 1 3}$ & -5876 & 18226.7 & -382.4 \\
$\mathbf{2 0 1 4}$ & 408.5 & 8423.7 & 2672.6 \\
$\mathbf{2 0 1 5}$ & 1135.4 & 2689.9 & 276.1 \\
$\mathbf{2 0 1 6}$ & 1135.4 & 6625.8 & 276.1 \\
$\mathbf{2 0 1 7}$ & 1231.2 & 7298.4 & 279.5 \\
\hline
\end{tabular}

\section{Copyrights}

Copyright for this article is retained by the author(s), with first publication rights granted to the journal.

This is an open-access article distributed under the terms and conditions of the Creative Commons Attribution license (http://creativecommons.org/licenses/by/4.0/). 